\title{
Proposed Model for Inter-Institutional Collaboration on Instructional Design Projects
}

\author{
Andrew Blick \\ Director of Planning, Assessment, and Instructional Design \\ Western Washington University \\ Todd Waters \\ Instructional Designer \\ Whatcom Community College
}

\begin{abstract}
Author Notes
Andrew Blick is Director of Planning, Assessment, and Instructional Design in Outreach and Continuing Education at Western Washington University in Bellingham, WA. He is a doctoral candidate in Technical Communication and Rhetoric at Texas Tech University.

Todd Waters is Instructional Designer and Faculty at Whatcom Community College in Bellingham, WA. He holds a Ph.D. in Educational Leadership and Assessment from Northcentral University
\end{abstract}




\begin{abstract}
Instructional design requests are multi-faceted and complex, necessitating a broad skill set and efficacious problem-solving procedures. While individual instructional designers in higher education are effective in their work, partnering with designers from other higher education institutions allows them to leverage one another's experiences, skills, and approaches to these complex design requests. There is much research regarding instructional design processes, but there is none that addresses inter-institutional collaborative efforts to address complicated instructional design requests from faculty and subject-matter experts. In this article, we review current trends and discussions of instructional design models and practices and applicable communication theories and practices. We then propose a model for cross-institutional collaboration based on instructional design, communication, and collaborative processes. Keywords: collaboration, instructional design, inter-institutional, theory, communication, framework, project management
\end{abstract}




\section{Introduction}

This article provides an opportunity to reflect on the work of instructional designers at higher education institutions, specifically looking at opportunities for inter-institutional collaboration and peer networking. We, as practicing instructional designers at different institutions, have engaged in an intentional, informal process of sharing ideas, methods, and solutions related to instructional design projects and requests. Through this process, we have recognized the benefits of this collaborative work and have seen improvements in our day-to-day instructional design tasks, our strategy for assisting faculty and subject-matter experts in development projects, and contributing meaningful work at our respective institutions. In addition to enriching our experiences as instructional designers, this collaborative approach creates an opportunity to receive frequent feedback and ideas from colleagues from other institutions.

The role of the instructional designer in higher education is multi-faceted and is primarily centered around supporting faculty and subject-matter experts with course design, alignment, and assessment. Support is often provided through consultations and presentations, both in in-person and online modalities. For this article, faculty are discipline specialists who engage in the teaching and learning processes, and subject-matter experts may be involved in the curriculum and course development process, although they may not necessarily teach. The work of the instructional designer in higher education has continued to evolve, adapting to changes in educational technology, new instructional theories, and faculty and subject-matter expert needs. As such, instructional designers are expected to have a robust knowledge of instructional practices and a foundation in learning theory and alignment work. Typically, instructional designers have opportunities to collaborate at inter-institutional conferences and retreats; these 
events are intentionally devised to provide designers with the chance to network and share ideas. However, conferences tend to focus on ideation and networking versus building models of sustained, collaborative support. By engaging in informal and frequent cross-institutional collaboration and communication, instructional designers can benefit from sharing ideas and practices.

Substantial literature has been written on the role of the instructional designer in the teaching and learning process and how the instructional designer can support faculty and subjectmatter experts (Kebaetse \& Sims, 2016; Kuhlenschmidt, 2010; Rothwell et al., 2015; Roytek, 2010; Williams van Rooij, 2010). However, few pieces have been authored that explore how instructional designers can better manage and process their work if they engage with other instructional designers from other institutions to discuss ideas, develop strategies for working with faculty and subject-matter experts, and collaborate on projects. Typically, process-oriented studies apply project and task management principles to address instructor development and design requests rather than focusing on the work process of the instructional designer. Our preliminary investigation of the literature demonstrated that additional inquiry is needed as it pertains to opportunities for this inter-institutional collaborative work to enhance the support process. Recognizing these gaps in the instructional design literature, we review trends in instructional design surrounding approaches to faculty support and managing requests, including outlining areas of potential concern. We look to models from communication studies and allied disciplines grounded in theories and managing collaborative projects that can inform collaborative instructional design practices.

After reviewing the literature and analysis of select interdisciplinary models, we propose and elucidate a new model for inter-institutional support and collaboration. Our goal for this 
model is to open a conversation on opportunities to intentionally and regularly engage in collaborative discussions on instructional design work centered around specific projects and problems. The model can be used as a tool to help facilitate these discussions and serve as a heuristic for engaging in collaborative, inter-institutional work on instructional design projects. The model design is based on the scholarship and inquiry areas covered in the literature review and is intended to serve as a representation of practical workflow aligned with scholarship and research-based practices. As instructional designers who participate in conversations on practices and methods of providing faculty support, we have constructed this model to be incorporated into collaborative work within our profession.

\section{Literature Review}

Instructional design theory is positioned as a dynamic approach to designing, developing, and supporting the teaching and learning process. As instructional designers, our work can draw from a variety of instructional theories, allowing for a bricolage approach to constructing an instructional design paradigm; this approach is recognized heavily in the literature, considering the history of the field (Reigeluth \& Carr-Chellman, 2009; Snelbecker, 1999a; and Snelbecker, 1999b). The literature review is divided into four segments, each corresponding and informing the categories used in our model. The section "Perspectives from Communication and Organizational Theory" informs the "Relational-Level" of our model, building an understanding of how theories and strategies can inform our work; "Considerations for the Instructional Design Process" addresses the "Task-Level" and provides a direct connection to instructional design work; and finally, “Opportunities for Cross-Institutional Support” integrates opportunities for inter-institutional collaboration. The final section of the literature review, "Opportunities for New Models and Approaches," brings key ideas forward for continuing the discussion. 


\section{Perspectives from Communication and Organizational Theory}

Drawing in knowledge-making and communication management from allied fields, technical communication provides an opportunity to evaluate work patterns of individuals in roles critical to the teaching and learning process. Focusing on organization and collaboration of content management from a technical communication perspective, Batson and Feinberg (2008) propose a model for managing collaboration in information design projects and tasks that incorporate subject-matter experts and communication specialists. Additionally, Kline and Barker (2012) present the CANFA model—collaborate, apply, negotiate, facilitate, and activate - as an opportunity to integrate collaboration directly and intentionally into technical communication work. Investigating the overlap between instructional designers and technical communicators' collaborative work patterns can assist instructional design in the investigation of opportunities and models for peer support through the cross-institutional collaboration of instructional design projects and problems.

Human communication theory positions and supports the need for effective collaborative strategies to provide additional insight into the instructional design process (Mowlana, 2019). Schema theory posits that people develop and compartmentalize perceptions based on lived experiences (Neumann \& Kopcha, 2018). Per our personal experiences as instructional designers, the challenges of faculty and subject-matter experts are often based on compartmentalized notions of design processes and perceived roles; complex requests emerge from assumptions nested in the requestor's schemata and are often based on the instructional designer's perceived role, processes, capabilities, and resources (Campbell, 1999 and Halupa, 2019). A competent communicator recognizes these schemata as potential points of convergence or divergence and adjusts their approach to working with the requestor appropriately. Reflecting 
on the earlier discussion of Kebaetse and Sims's (2016) and Kuhlenschmidt's (2010) work in instructional design, we can develop frameworks for responding to and supporting differing requests.

Prioritizing the needs of design requests necessitates employing the situational theory of problem-solving to ensure tasks are orientated and addressed properly (Chen, Hung-Baesecke, \& Kim, 2017; Chen et al., 2018). The situational theory of problem-solving proposes a model that addresses the tendency for people in support roles to place the needs of others before their own proven processes and requires honing effective communication skills, heightening communication competence, and being able to interpret and articulate contexts to prioritize tasks (Chen et al., 2018).

Giles and Ogay (2016) conceived communication accommodation theory, which postulates that communication interactions are perpetuated by preconceived notions, immediate needs, and ongoing problem-solving efforts of conversation partners. Communication accommodation theory requires oscillation between task and relationship-orientation and can provide a framework to help structure and articulate how inter-institutional collaboration can enrich the instructional design process.

\section{Considerations for the Instructional Design Process}

A core role for instructional designers in higher education is to provide support to instructional units. Specifically, instructional designers often work closely with the institution's faculty to develop course materials, align learning outcomes, and create engaging and meaningful teaching and learning contexts. Recognizing a gap in understanding the work process of instructional designers in responding to requests from faculty and subject-matter experts, Roytek (2010) categorized patterns of instructional design work, giving special attention to the 
tools and approaches that instructional designers use in their processes. Select efficiency methodologies that Roytek identified in this process that focus on collaboration were to rotate instructional designers on projects, cross-utilize learning from other projects, and share strategies from other teams. As Roytek's suggestions focus on collaboration within a single institution, what is missing from this narrative is the work of supporting faculty and subject-matter experts and employing strategies of sharing experiences and ideas across institutions to better respond to these requests for support.

Faculty and subject-matter experts commonly perceive that instructional designers offer basic educational technology support, for example, in learning management system support (Lieberman, 2017). However, instructional designers provide a more comprehensive array of support and expertise than what is frequently sought. As a result of this discrepancy, faculty and subject-matter experts often range in their levels of reception of instructional design services (Halupa, 2019). To better understand and support faculty based on their levels of comfort and use of technologies in the teaching and learning process, Kuhlenschmidt (2010) applied Roger's 2003 innovation framework to argue that faculty can be categorized into various groups: innovators who take the initiative and explore independently; early adopters who learn technologies and participate in collaborative efforts to understand the technologies better; late adopters who comprise the majority of faculty and will engage once they see the impact of the new ideas and technologies; and laggards who rely on colleagues and see a minimum value in the technologies (2010, pp. 260-261). Kuhlenschmidt's categorization work is important for understanding the support process and the socio-historical context for how to tailor instructional design strategies and methods for a particular audience. Layering the work on identifying models for faculty support, such as that done by Kebaetse and Sims (2016), onto the categories discussed 
by Kuhlenschmidt and considering the ethical challenges presented in Osgulthorpe et al. (2003) can give the instructional designer a method of identifying strategies and methods that may help support and manage faculty requests. For example, in crafting a development plan for a course design project, understanding where a faculty developer is on the innovation framework scale will allow the designer to tailor the needed support to that individual, ensuring that both the faculty and the instructional designer know what level of support will be offered and what the expectations will be of their contributions.

As the goal of most instructional design positions is to support faculty and subject-matter experts in developing meaningful learning experiences, examining the literature on project management as it relates to collaboration is necessary. Specifically, literature on applications of project management provides insight into the work patterns of instructional designers while revealing where opportunities for collaboration may fit. Instructional designers need to not only be familiar with the instructional design process but engaged in understanding and applying strategies from project management (Williams van Rooij, 2010). A strategy discussed by Rothwell (2015) is the importance of clear communication and transparency in this process to ensure project milestones and objectives are met. Reviewing the proposed models, while collaboration and communication are crucial elements in the field, they can easily be relegated from the planning process due to high levels of work and competing timelines. By intentionally including a cross-institutional collaboration model grounded in systems communication, instructional designers can review project milestones and communication strategies with colleagues who can review and ensure that communication is occurring (Ford \& Lerner, 1992). This approach can facilitate the collaboration process and produce synergistic results. 


\section{Opportunities for Cross-Institutional Support}

Discussions on collaboration in instructional design have primarily focused on the work between the instructional designer and the faculty member or subject-matter expert (Halupa, 2019). However, little is focused on the work that can occur between instructional designers to support projects. Arguments within the instructional development space have evolved from positioning the instructional designer from solely a supporting role to that of a partner in the teaching and learning process (Campbell, 1999). Placing value on interpersonal skills, specifically clear, effective communication about instructional design work, has been recognized as a critical skill for instructional designers (Rothwell et al., 2015). The narrative of positioning the instructional designer as an individual who can contribute to the teaching and learning process brings forth questions about what instructional designers can do together to reflect on and examine their collaborative work patterns.

Instructional designers establish rapport and are positioned to deliver meaningful feedback to colleagues using strategic communication, specifically situational knowledge obtained through experience, professional development, dialectical tensions and convergences, and feedback loops (Garcia-Morales, Martin-Rojas, \& Lardon-Lopez, 2018). Specific dialectical tensions, such as agreeableness and disagreeableness, should be carefully monitored and interpreted throughout the support process. Through establishing these relationships and by positioning informal professional relationships as a support model, an inter-institutional approach can provide a more objective sounding board for ideas and problems.

\section{Opportunities for New Models and Approaches}

Through our examination of trends and ideas presented in the scholarship of instructional design, we identified an opening in the conversation around the topic of collaboration and inter- 
institutional networking opportunities. In addition, examining trends in instructional design reveals the unique interdisciplinary and intersectional nature of instructional design work, granting further credence to the importance of collaboration and sharing of ideas. Given that the work that we are proposing is centered around communication and collaboration, continuing to build a model based solely on instructional design theory will omit an opportunity to draw on ideas from different disciplines and traditions, particularly those investigated in communication studies, organizational theory, and technical communication: An agile model that promotes the cross-institutional collaboration process, particularly with handling complex requests from faculty and subject-matter experts, is paramount.

\section{Proposed Model for Inter-Institutional Collaboration of Instructional Design Projects}

The theories and models presented in the literature review are used to better understand the relationships and productivity of organizational units, but they lack a framework that positions them within an inter-institutional, collaborative space. Building on the work of Giles and Ogay (2007), we have constructed a model that marries communication support theories, specifically communication accommodation theory, with instructional design and collaboration approaches to demonstrate the potential of inter-institutional cooperation. The goal of this model is to assist institutions and instructional designers in identifying and managing opportunities for inter-institutional collaboration.

\section{Model Organization}

The combined theories and collaboration approaches create a sequential model that allows users to move seamlessly from one "Step" to another. The model can be used in its entirety or be broken down into specific stages to support defined projects, at the discretion of the collaboration team. The titles and contexts for each "Step" were determined by us, the 
instructional designers, after reviewing the scholarship and basing it on experiences managing tasks and determining workflow processes. The "Step" presented in the left column articulates our vision for task and project management. The "Relational-Level" column expands on and interrogates the relationship within the communicative context. The "Task-Level" column connects the relational level to instructional design projects and opportunities. Last, the “Collaboration" column contains suggestions for cross-institutional support and professional collaboration to respond to and develop solutions to instructional design projects. While each section provides context for the project team to be able to question their process and gives questions for considering how inter-institutional collaboration can be infused into an existing process, the "Collaboration" segment of the model presents prompts and questions to consider when communicating and working together cross-institutionally.

\section{Steps in Project Workflow}

The model contains steps towards completing a collaborative work process. A good workflow model should contain a series of milestones that allows collaborators to determine next steps and address potential problems (Rothwell, 2015). This model contains six "Steps": identify, analyze, determine, manage tasks, project workflow begins, and project completion. The first step is to identify the socio-historical context, which requires the designers to acknowledge the requestor's position in the higher education institution, experiences with instructional design and technology, and feelings of apprehension towards change (Chen et al., 2018; Garcia-Morales et al., 2018). This prepares the designers to build a successful rapport with the requestor. Second, the designers analyze the requestor's placement on a point of convergence and divergence scale (Neumann \& Kopcha, 2018). A competent designer's communication is used in ways that recognize how the requestor perceives instructional design experience and critique as these 
potential points of convergence or divergence and adjusts their approach to working with the requestor appropriately (Neumann \& Kopcha, 2018). These first two steps necessitate communication competency and may account for the success or failure of the communication interaction between the designers and the requestor.

Following analysis, the designers determine the needs of the faculty requesting assistance. Identifying the specific needs of the faculty member is particularly helpful during this step and asking pointed questions to identify the specific issues or problems in need of resolution can enhance efficiency. Following the acquiescence of the problems, the designers establish a set of tasks and plans to address the requestor's needs. This work can be done collaboratively to determine the best course of action using all available resources. Then, project workflow begins, which includes setting project milestones and a communication plan. The final step in this process is project completion, which centers on reflecting on the project workflow, identifying areas of potential review and improvement, and eliciting feedback from stakeholders.

\section{Table 1}

Model of application of inter-institutional collaboration to support instructional design work.

\begin{tabular}{|l|l|l|l|}
\hline Step & Relational-Level & Task-Level & Collaboration \\
\hline $\begin{array}{l}\text { Project or } \\
\text { Task } \\
\text { Management }\end{array}$ & $\begin{array}{l}\text { Perspectives from } \\
\text { Communication and } \\
\text { Organizational Theory }\end{array}$ & $\begin{array}{l}\text { Considerations for the } \\
\text { Instructional Design } \\
\text { Process }\end{array}$ & $\begin{array}{l}\text { Opportunities for Cross- } \\
\text { Institutional Support }\end{array}$ \\
\hline $\begin{array}{l}\text { Identify the } \\
\text { socio- } \\
\text { historical } \\
\text { context }\end{array}$ & $\begin{array}{l}\text { Understand the socio- } \\
\text { historical context of the } \\
\text { requestor's message and } \\
\text { context. Situational } \\
\text { knowledge helps } \\
\text { identify the best way to } \\
\text { proceed with problem- } \\
\text { solving (Chen et al., } \\
\text { 2018; Garcia-Morales et } \\
\text { al., 2018). }\end{array}$ & $\begin{array}{l}\text { Has the instructor had } \\
\text { trustrations with } \\
\text { technology/teaching } \\
\text { before bringing to their } \\
\text { interaction and request? } \\
\text { terrible past experiences } \\
\text { with someone in the } \\
\text { instructional design } \\
\text { position. What is their }\end{array}$ & $\begin{array}{l}\text { ldentify contexts and } \\
\text { plans for approaching } \\
\text { similar and different } \\
\text { behavions among faculty } \\
\text { at other institutions. }\end{array}$ \\
\hline
\end{tabular}




\begin{tabular}{|c|c|c|c|}
\hline & & $\begin{array}{l}\text { comfort level with } \\
\text { adopting new } \\
\text { technologies, and what } \\
\text { processes could be } \\
\text { employed to better } \\
\text { support different } \\
\text { teaching and learning } \\
\text { approaches? } \\
\text { (Kuhlenschmidt, 2010) }\end{array}$ & \\
\hline $\begin{array}{l}\text { Analyze } \\
\text { where the } \\
\text { requester } \\
\text { falls on a } \\
\text { convergence/ } \\
\text { divergence } \\
\text { scale }\end{array}$ & $\begin{array}{l}\text { Analyze the barometer } \\
\text { of the level of social } \\
\text { distance between the } \\
\text { interactants due to the } \\
\text { socio-historical context } \\
\text { (Giles \& Ogay, 2007). } \\
\text { Reference Roger's } \\
\text { innovation framework to } \\
\text { determine where the } \\
\text { requestor falls: } \\
\text { innovators, early } \\
\text { adopters, late adopters, } \\
\text { or laggards (2010). }\end{array}$ & $\begin{array}{l}\text { Are there perceived } \\
\text { points of divergence? } \\
\text { Are there points of } \\
\text { perceived convergence? } \\
\text { This determines the way } \\
\text { accommodation should } \\
\text { be communicated. } \\
\text { Which frameworks and } \\
\text { models of support may } \\
\text { fit the situation? } \\
\text { (Kebaetse \& Sims, } \\
\text { 2016) }\end{array}$ & $\begin{array}{l}\text { What methods have } \\
\text { instructional design } \\
\text { teams implemented at } \\
\text { different institutions to } \\
\text { address problems and to } \\
\text { resolve ongoing } \\
\text { challenges? What are } \\
\text { meaningful channels of } \\
\text { sharing this information } \\
\text { cross-institutionally? }\end{array}$ \\
\hline $\begin{array}{l}\text { Determine } \\
\text { the needs of } \\
\text { the faculty }\end{array}$ & $\begin{array}{l}\text { Identify the specific } \\
\text { needs of the instructor } \\
\text { based on their request. } \\
\text { Situate requests based } \\
\text { on models of } \\
\text { prioritization (Batson \& } \\
\text { Feinberg } 2008 \text { and Chen } \\
\text { et al., 2018). }\end{array}$ & $\begin{array}{l}\text { Which project } \\
\text { management strategies } \\
\text { could be implemented to } \\
\text { support faculty } \\
\text { members? (Rothwell, } \\
2015 \text { and Williams van } \\
\text { Rooij, 2010) }\end{array}$ & $\begin{array}{l}\text { Share different needs of } \\
\text { faculty and methods of } \\
\text { addressing problems and } \\
\text { tasks efficiently. } \\
\text { Discussion of tools and } \\
\text { approaches used at } \\
\text { different institutions } \\
\text { may provide insight into } \\
\text { ways to improve } \\
\text { processes. Exemplars } \\
\text { and models of success } \\
\text { can be shared at this } \\
\text { stage, as well as failures } \\
\text { and untested potential } \\
\text { opportunities. }\end{array}$ \\
\hline $\begin{array}{l}\text { Manage } \\
\text { tasks by } \\
\text { determining } \\
\text { the next steps } \\
\text { to solving the }\end{array}$ & $\begin{array}{l}\text { Identify the tasks } \\
\text { required to solve the } \\
\text { problem, including } \\
\text { determining immediacy, } \\
\text { if research is required, }\end{array}$ & $\begin{array}{l}\text { Composing a list of } \\
\text { tasks with the instructor } \\
\text { ensures that the } \\
\text { instructor perceives the } \\
\text { design process as }\end{array}$ & $\begin{array}{l}\text { Establish shared models } \\
\text { of communication and } \\
\text { task prioritization that } \\
\text { can benefit instructional } \\
\text { designers at different }\end{array}$ \\
\hline
\end{tabular}




\begin{tabular}{|c|c|c|c|}
\hline problem & $\begin{array}{l}\text { and setting project } \\
\text { milestones (Chen et al., } \\
\text { 2018). } \\
\text { Communication } \\
\text { categories to be } \\
\text { addressed include } \\
\text { immediacy, impact on } \\
\text { the receiver's processes, } \\
\text { and planning/mapping } \\
\text { tasks, and relational } \\
\text { planes. }\end{array}$ & $\begin{array}{l}\text { collaborative and not } \\
\text { transactional (Giles \& } \\
\text { Ogay, 2007). } \\
\text { Determine steps to lead } \\
\text { to accommodation based } \\
\text { on divergence or } \\
\text { convergence behaviors } \\
\text { and decipher when the } \\
\text { task needs to be } \\
\text { completed and how it } \\
\text { affects workflow (Giles } \\
\& \text { Ogay, 2007). }\end{array}$ & $\begin{array}{l}\text { institutions. Share } \\
\text { lessons learned from } \\
\text { successful and } \\
\text { unsuccessful project } \\
\text { management } \\
\text { experiences- } \\
\text { investigation and review } \\
\text { of collaboration models } \\
\text { (Kline \& Barker, 2012). }\end{array}$ \\
\hline $\begin{array}{l}\text { Project } \\
\text { workflow } \\
\text { begins }\end{array}$ & $\begin{array}{l}\text { The instructional } \\
\text { designer engages in } \\
\text { convergence signals } \\
\text { throughout the process } \\
\text { to accommodate by } \\
\text { using a wide range of } \\
\text { linguistic, paralinguistic, } \\
\text { and nonverbal features } \\
\text { to become more similar } \\
\text { to their sender's } \\
\text { behavior (Giles \& Ogay, } \\
\text { 2007). }\end{array}$ & $\begin{array}{l}\text { Work on completing the } \\
\text { project while managing } \\
\text { individual and team } \\
\text { tasks. Application of } \\
\text { project management } \\
\text { strategies to } \\
\text { instructional design } \\
\text { projects (Williams van } \\
\text { Rooij, 2010). Follow-up } \\
\text { emails, phone calls, and } \\
\text { other assurances are } \\
\text { utilized. }\end{array}$ & $\begin{array}{l}\text { Share project timelines } \\
\text { and duties to synergize } \\
\text { efforts to support faculty } \\
\text { at both institutions. } \\
\text { Investigate opportunities } \\
\text { for inter-institutional } \\
\text { collaboration on shared } \\
\text { resources (e.g., } \\
\text { document libraries, } \\
\text { training information). }\end{array}$ \\
\hline $\begin{array}{l}\text { Project } \\
\text { completion }\end{array}$ & $\begin{array}{l}\text { Upon completion of the } \\
\text { task, the goal should be } \\
\text { to establish a } \\
\text { convergence dynamic } \\
\text { with the sender so } \\
\text { interactants are more } \\
\text { comfortable working } \\
\text { together in the future. } \\
\text { Consider lessons learned } \\
\text { and integration of lived } \\
\text { experiences (Neumann } \\
\text { \& Kopcha, 2018). }\end{array}$ & $\begin{array}{l}\text { Review the project and } \\
\text { identify opportunities to } \\
\text { improve the process. } \\
\text { Results of successful } \\
\text { project completion } \\
\text { should increase the } \\
\text { designer's social capital } \\
\text { and influence at an } \\
\text { institutional level } \\
\text { (Rottman, 2008). }\end{array}$ & $\begin{array}{l}\text { Completed projects } \\
\text { shared inter- } \\
\text { institutionally increase } \\
\text { the designers' social } \\
\text { capital and influence } \\
\text { inter-institutionally } \\
\text { (Rottman, 2008). }\end{array}$ \\
\hline
\end{tabular}

The combination of strategic communication behaviors with management of instructional design tasks with concurrent inter-institutional collaboration facilitates a dynamic process of problem-solving with cross-institutional colleagues that can deliver meaningful results in 
supporting faculty and subject-matter experts. The model demonstrates how these relationships and tasks at different levels interact, though the model implies a linear design and adherence to this process, instructional designers may choose to employ specific aspects of the model at different stages in the design process or engage with multiple aspects simultaneously. By introducing each "Step" associated with the model, then presenting the model itself, the intent is to inform about the process of relationship-establishment, task orientation, and inter-institutional collaboration upon receipt of the request.

The management and assignment of tasks of instructional designers at the institutional level should be clearly articulated early in the process to ensure effective and meaningful collaboration. The opportunity to network with instructional designers from other institutions, particularly through the lens of this model, allows for a more efficient and rewarding experience that benefits the instructional designers, faculty, and subject-matter experts alike. While the model presents a structure for understanding how this collaboration can work, each instructional designer and institution will need to test and determine how the various components of the model could fit within their workflow to benefit their processes.

\section{Sample Model Application}

As an illustration of how this model can work, if an instructional design unit from an institution were interested in developing a professional development program, they could join with colleagues from another institution to create a joint project, drawing on their shared experiences and ideas. The table below demonstrates how each step could be applied in this scenario. 
Table 2

Application of inter-institutional collaboration model on developing a new professional development program.

\begin{tabular}{|c|c|c|c|}
\hline Step & Relational-Level & Task-Level & Collaboration \\
\hline $\begin{array}{l}\text { Project or } \\
\text { Task } \\
\text { Management }\end{array}$ & $\begin{array}{l}\text { Perspectives from } \\
\text { Communication and } \\
\text { Organizational Theory }\end{array}$ & $\begin{array}{l}\text { Considerations for the } \\
\text { Instructional Design } \\
\text { Process }\end{array}$ & $\begin{array}{l}\text { Opportunities for Cross- } \\
\text { Institutional Support }\end{array}$ \\
\hline $\begin{array}{l}\text { Identify the } \\
\text { socio- } \\
\text { historical } \\
\text { context }\end{array}$ & $\begin{array}{l}\text { What programs and } \\
\text { professional } \\
\text { development have been } \\
\text { offered by each } \\
\text { institution in the past? } \\
\text { What can be brought } \\
\text { forth for new } \\
\text { programming? }\end{array}$ & $\begin{array}{l}\text { What was the feedback } \\
\text { to those programs? } \\
\text { What are the } \\
\text { requirements for starting } \\
\text { new programs? }\end{array}$ & $\begin{array}{l}\text { What are the } \\
\text { opportunities for } \\
\text { collaboration? } \\
\text { How can tasks be } \\
\text { divided up so that both } \\
\text { institutions can benefit } \\
\text { from the collaboration? }\end{array}$ \\
\hline $\begin{array}{l}\text { Analyze } \\
\text { where the } \\
\text { requester } \\
\text { falls on a } \\
\text { convergence/ } \\
\text { divergence } \\
\text { scale }\end{array}$ & $\begin{array}{l}\text { What can each } \\
\text { institution provide in } \\
\text { terms of ideas and } \\
\text { support for this project } \\
\text { to benefit both } \\
\text { institutions? }\end{array}$ & $\begin{array}{l}\text { What programs have } \\
\text { already been developed } \\
\text { and implemented? } \\
\text { What are the individual } \\
\text { needs of each } \\
\text { institution? }\end{array}$ & $\begin{array}{l}\text { How can the team map } \\
\text { individual and shared } \\
\text { needs to better } \\
\text { understand how } \\
\text { development can be } \\
\text { efficiently streamlined } \\
\text { across a cross- } \\
\text { institutional team? }\end{array}$ \\
\hline $\begin{array}{l}\text { Determine } \\
\text { the needs of } \\
\text { the faculty }\end{array}$ & $\begin{array}{l}\text { What is the best method } \\
\text { of collecting information } \\
\text { from and including the } \\
\text { faculty perspective on a } \\
\text { professional } \\
\text { development program? }\end{array}$ & $\begin{array}{l}\text { What are the specific } \\
\text { goals and outcomes of } \\
\text { the professional } \\
\text { development program? }\end{array}$ & $\begin{array}{l}\text { How do the needs of } \\
\text { faculty overlap between } \\
\text { each institution? } \\
\text { What are the } \\
\text { differences? } \\
\text { Will a collaborative } \\
\text { effort support a new } \\
\text { program? }\end{array}$ \\
\hline $\begin{array}{l}\text { Manage } \\
\text { tasks by } \\
\text { determining }\end{array}$ & $\begin{array}{l}\text { What tasks will be } \\
\text { required to complete the } \\
\text { professional }\end{array}$ & $\begin{array}{l}\text { What standards does the } \\
\text { team need to develop to } \\
\text { ensure consistency in }\end{array}$ & $\begin{array}{l}\text { How will each team } \\
\text { member be assigned } \\
\text { tasks on the project }\end{array}$ \\
\hline
\end{tabular}




\begin{tabular}{|c|c|c|c|}
\hline $\begin{array}{l}\text { the next steps } \\
\text { to solving the } \\
\text { problem }\end{array}$ & $\begin{array}{l}\text { development } \\
\text { offering(s)? } \\
\text { How can the team } \\
\text { members participate in } \\
\text { creating a road } \\
\text { map/development plan } \\
\text { for the program? }\end{array}$ & $\begin{array}{l}\text { developing materials } \\
\text { and content? } \\
\text { How can tasks be } \\
\text { chunked into meaningful } \\
\text { segments for the } \\
\text { instructional design } \\
\text { team? }\end{array}$ & $\begin{array}{l}\text { plan? } \\
\text { What are the } \\
\text { expectations for the } \\
\text { communication flow } \\
\text { related to project tasks? }\end{array}$ \\
\hline $\begin{array}{l}\text { Project } \\
\text { workflow } \\
\text { begins }\end{array}$ & $\begin{array}{l}\text { How will the team } \\
\text { monitor and manage } \\
\text { communication between } \\
\text { the instructional design } \\
\text { team and the faculty? }\end{array}$ & $\begin{array}{l}\text { How will the project } \\
\text { team build the project } \\
\text { and continue to } \\
\text { implement project } \\
\text { management strategies } \\
\text { to manage } \\
\text { communication? }\end{array}$ & $\begin{array}{l}\text { How will the team } \\
\text { communicate milestones } \\
\text { and expectations from } \\
\text { the team members and } \\
\text { the institutions? }\end{array}$ \\
\hline $\begin{array}{l}\text { Project } \\
\text { completion }\end{array}$ & $\begin{array}{l}\text { What worked and what } \\
\text { didn't for the program as } \\
\text { part of the collaborative } \\
\text { project? }\end{array}$ & $\begin{array}{l}\text { What form of share-out } \\
\text { for the project will be } \\
\text { done for stakeholders, } \\
\text { including reviewing the } \\
\text { opportunities and } \\
\text { challenges of a cross- } \\
\text { institutional } \\
\text { collaboration? }\end{array}$ & $\begin{array}{l}\text { How will the evaluation } \\
\text { and revision phase of the } \\
\text { project allow for the } \\
\text { team to make } \\
\text { adjustments for future } \\
\text { projects? }\end{array}$ \\
\hline
\end{tabular}

\section{Practical Experience with the Model}

Our experiences as instructional designers who have actively engaged in a collaborative approach to projects and tasks have directly informed both how we crafted this model and how we imagined it could be applied. To expand on this application, in our development of professional development opportunities, we have shared our experiences with different programming ideas and provided examples of past programs with participant feedback and future ideas (analyze and identify), supported each other in the mapping of faculty and institutional needs to potential programming (determine), created tasks and milestones for our independent projects and supports for each other (manage tasks and workflow), and finally reviewed 
programs and opportunities to provide guidance and ideas for moving forward (project completion). Through this collaborative process, we have enhanced our programming and our methods of support through the direct input of a colleague from another institution. This feedback created an opportunity for a critical review of offerings and opportunities while simultaneously adding another layer of support for developing ideas for future endeavors and projects.

\section{Conclusion}

This article establishes a model for integrating cross-institutional collaboration into the instructional design process by providing opportunities for instructional designers to network professionally, share ideas, and develop peer support networks to work through ideas and solutions to projects. The proposed model can be referenced and leveraged at the relational, task, or collaboration level, though these processes can occur simultaneously. Instructional designers should reference the model to ascertain effective communication behaviors to apply to their interpersonal relationships with faculty and subject-matter experts and review the collaborative recommendations to elevate their support network to an inter-institutional level.

We present this as the first step to better understanding this process; while this model is based on literature in instructional design, communication studies, technical communication, and organizational theory, additional work is needed to test this model in different instructional design projects to determine how this framework could be applied in different contexts and to further our understanding of how instructional designers can participate in collaborative problem-solving and program development. Specific studies that pilot the model and commentate on its structure and framing are needed. Additional interdisciplinary devices may need to be applied to contribute to the model's robustness. We hope that this model serves as a 
call to engage instructional designers in professional, inter-institutional collaborative discussions about their work process that will enrich their experiences and those they support. 


\section{References}

Batson, L. \& Feinberg, S. (1998). Managing collaboration: Adding communication and documentation environment to a product development cycle. In G. F. Hayhoe \& H. M. Grady (Eds.), Connecting people with technology: Issues in professional communication (pp. 207-217). Amityville, NY: Baywood. http://dx.doi.org/10.2190/CPTC19

Campbell, K. (1999). Tensionalities in the collaborative instructional design process. International Journal of Qualitative Studies in Education, 12(4), 381-399. https://doi.org/10.1080/095183999236042

Chen, L., Uemura, H., Goda, Y., Okubo, F., Taniguchi, Y., Oi, M., \& Yamada, M. (2018). Instructional design and evaluation of science education to improve collaborative problem solving skills. Society for Information Technology \& Teacher Education International Conference, 1364-1369.

Chen, Y., Hung-Baesecke, C., \& Kim, J. (2017). Identifying active hot-issue communicators and subgroup identifiers: Examining the situational theory of problem solving. Journalism \& Mass Communication Quarterly, 94(1), 124-147. https://doi.org/10.1177/1077699016629371

Ford, D. H. \& Lerner, R. M. (1992). Developmental systems theory: An integrative approach. Thousand Oaks, CA: Sage Publications, Inc.

Garcia-Morales, V. J., Martín-Rojas, R., \& Lardón-López, M. E. (2018). Influence of social media technologies on organizational performance through knowledge and innovation. Baltic Journal of Management, 13(3), 345-367. https://doi.org/10.1108/BJM-04-20170123

Giles, H. \& Ogay, T. (2007). Communication accommodation theory. In B. B. Whaley \& W. 
Samter (Eds.), Explaining communication: Contemporary theories and exemplars (pp. 293-310). Mahwah, NJ: Lawrence Erlbaum. https://doi.org/10.1002/9781118766804.wbiect056

Halupa, C. (2019). Differentiation of roles: Instructional designers and faculty in the creation of online courses. International Journal of Higher Education, 8(1), 55-68. https://doi.org/10.5430/ijhe.v8n1p55

Kebaetse, M. B. \& Sims, R. (2016). Using instructional consultation to support faculty in learner-centered teaching. Journal of Faculty Development, 30(3), 31-40.

Kline, J. \& Barker, T. (2012). Negotiating professional consciousness in technical communication: A community of practice approach. Technical Communication, 59(1), $32-48$.

Kuhlenschmidt, S. (2010). Issues in technology and faculty development. In K. J. Gillespie \& D. L. Robertsons (Eds.), A guide to faculty development (2nd ed.). (pp. 259-274). San Francisco, CA: Jossey-Bass.

Lieberman, M. (2017). Instructional design teams: Beyond the numbers. Inside Higher Ed. Retrieved from: https://www.insidehighered.com/digitallearning/article/2017/12/06/instructional-designers-weigh-benefits-and-drawbacks-teamsizes

Mowlana, H. (2019). Human communication theory: a five-dimensional model. The Journal of International Communication, 25(1), 3-33. https://doi.org/10.1080/13216597.2018.1560351

Neumann, K. L. \& Kopcha, T. J. (2018). The use of schema theory in learning, design, and technology. TechTrends, 62(5), 429-431. https://doi.org/10.1007/s11528-018-0319-0 
Osgulthorpe, R. T., Osgulthorpe, R., Jacob, W. J., \& Davies, R S. (2003). The moral dimensions of instructional design. Educational Technology, 43(2), 19-23.

Reigeluth, C. M. \& Carr-Chellman, A. A. (2009). Understanding instructional theory. In C. M. Reigeluth \& A. A. Carr-Chellman (Eds.), Instructional-design theories and models, Volume III: Building a common knowledge base. (pp. 3-26). New York, NY: Routledge.

Rothwell, W. J., Benscoter, B., King, M., \& King, S. B. (2015). Mastering the instructional design process: A systematic approach (5th ed.). Hoboken, NJ: Wiley.

Rottman, J. W. (1998). Successful knowledge transfer within offshore supplier networks: A case study exploring social capital in strategic alliances. Journal of Information Technology, 23(1), 31-43. https://doi.org/10.1057/palgrave.jit.2000127

Roytek, M. A. (2010). Enhancing the instructional design efficiency: Methodologies employed by instructional designers. British Journal of Educational Technology, 41(2), 170-180. https://doi.org/10.1111/j.1467-8535.2008.00902.x

Snelbecker, G. E. (1999). Current progress, historical perspective, and some tasks for the future of instructional theory. In C. M. Reigeluth (Ed.), Instructional-design theories and models, Volume II: A new paradigm of instructional theory. (pp. 653-674). Mahwah, NJ: Lawrence Erlbaum Associates.

Snelbecker, G. E. (1999). Some thoughts about theories, perfection, and instruction. In C. M. Reigeluth (Ed.), Instructional-design theories and models, Volume II: A new paradigm of instructional theory. (pp. 31-47). Mahwah, NJ: Lawrence Erlbaum Associates.

Williams van Rooij, S. (2010). Project management in instructional design: ADDIE is not enough. British Journal of Educational Technology, 41(5), 852-864. https://doi.org/10.1111/j.1467-8535.2009.00982.x 